\title{
Evaluate Strategy Spartan Gym Pekanbaru With Using The Method Of Balanced Scorecard
}

\author{
Nofrizal \\ Dosen Fakultas Ekonomi Universitas Lancang Kuning \\ Jalan Yos Sudarso KM 8 Rumbai \\ No Hp: 085225573311, E-mail: Nofrizalfe@unilak.ac.id
}

\begin{abstract}
The business environment is more that complex at the moment. Each the company makes strategic planning and implementation certainly in procesing will modify the strategy to adjust the business environment in order to match expected destination. Likewise Spartan gym engaged in fitness place of business is currently facing external and internal environment always changing and uncertain. Therefore, it is necessary to evaluate strategies to see if the strategy implemented at this time is appropriate to the business environment. The purpose of this study was to evaluate the strategy Spartan gym Pekanbaru using the method of balanced scorecard. The method in this research use qualitative research with the phases of the internal environment analysis like vision, mission, financial, human resource manajemen, marketing, external environment ,EFAS, IFAS and the balanced scorecard metode. Results from this study showed that after an evaluation of strategy on the Spartan gym Pekanbaru business position Spartan gym in a good position with a value of 3.973 .
\end{abstract}

Keywords: Evaluate, Business Strategy, Balanced Scorecard

Dalam lingkungan bisnis fitnes sewaktuwaktu dan terus menerus pasti akan menghadapi dimana lingkungan bisnis selalu berubah-ubah dan tidak pasti yang menuntut agar selalu menyesuaikan lingkungan bisnis tersebut dengan cara memodifikasi strategi yang sudah dibuat. Jika fitnes tersebut tidak melihat lingkungan bisnis yang berubah dengan cara melihat dari lingkungan eksternal dan internal perusahaan maka fitness tersebut sulit untuk maju dan bertahan pada persaingan kompetitif yang terus melakukan inovasi dan pengembangan caracara baru untuk meningkatkan keunggulan bersaing.

Begitupun pada Spartan gym Pekanbaru yang merupakan salah satu dari sekian banyak pemain di industri fitnes kota pekanbaru Provinsi Riau yang menghadapi perubahan lingkungan bisnis yang selalu berubah-ubah dan tidak pasti . Pada lingkungan internal Spartan gym mengalami yang berubah untuk menangkap peluang di kota pekanbaru karena setiap tahunnya fitnes ini mengalami peningkatan sampai akhirnya memiliki fasilitas ruangan baru, penambahan alat -alat fitnes yang memiliki teknologi yang canggih dan memiliki intsruktur yang bersertifikat dan berprestasi. Sedangkan pada lingkungan eksternal perubahan terjadi pada tingkat persaingan yang semakin kompetitif dimana jumlah tempat kebugaran di kota Pekanbaru sekitar 50 buah ditambah tingkat perekonomian yang semakin sulit serta perubahan selera konsumen. Namun dengan keadaan Spartan gym saat ini yang semakin berkembang dengan strategi-strategi yang dibuat tentu strategi yang diterapkan saat ini tidak akan bertahan lama karena strategi ini akan digunakan atau dicontek oleh pesaing dan pendatang baru pada industri kebugaran ini (fitnes).

Spartan gym saat ini Spartan gym tidak boleh berdiam diri saja dengan keadaan lingkungan bisnis saat ini maka Spartan gym perlu melakukan evaluasi. Evaluasi strategi berguna untuk melihat keadaan posisi bisnis pada saat ini dan melihat seberapa jauh tingkat pencapian dari strategi yang sudah direncanakan dan diimplimentasikan serta Spartan gym juga dapat membuat langkah-langkah perencanaan strategi di masa yang akan 
datang untuk menghadapi persaingan dan mengembangkan bisnis fitnesnya secara berkelanjutan, agar dapat bertahan dan memenangkan persaingan pada industri fitness di kota Pekanbaru, meskipun persaingan di dalam industri ini semakin ketat dan tidak mudah untuk di taklukan.

Fokus permasalahan

Berdasarkan latar belakang di atas peneliti mengambil fokus permasalahan yaitu bagaimana posisi bisnis Spartan gym setelah dilakukan evaluasi strategi dengan mengunakan metode balanced scorecard dan apakah sudah tepat perencanaan strategi yang sudah diterapkan oleh Spartan gym selama ini setelah dilakukan evaluasi dengan lingkungan bisnis saat ini.

Tujuan penelitian

Berdasarkan uraian perumusan permasalah penelitian di atas peneliti memiliki tujuan penelitian yaitu untuk mengevaluasi strategi Spartan gym saat ini diharapkan menjadi bahan masukan bagi Spartan gym Pekanbaru untuk mengembangkan perencanaan bisnis di masa yang akan datang

Landasan teori

Menurut Hunger dan Wheelen, (2009) manajemen strategis adalah serangkaian keputusan dan tindakan manajerial yang menentukan kinerja perusahaan dalam jangka panjang. Termasuk didalamnya pengamatan lingkungan (eksternal maupun internal), perumusan strategi (perencanaan jangka panjang), implementasi strategi, evaluasi, serta pengendalian. Bidang ilmu manajemen strategis menekankan pada pengamatan dan evaluasi peluang (opportunities) dan ancaman (threats) lingkungan dengan melihat kekuatan (strengths) dan kelemahan (weaknesses) perusahaan.

Sedangkan menurut Ismail Solihin (2012: 64) Menyatakan strategi bukan hanya sebagai cara untuk mencapai tujuan (way to achieve ends) melainkan mencakup pula penentuan berbagai tujuan itu sendiri yang ingin dicapai dimasa yang akan datang. strategi merupakan tindakan yang bersifat kontinyu dan terus menerus, serta dilakukan berdasarkan sudut pandang tentang apa yang diharapkan oleh para pelanggan di masa depan. Sehingga dibutuhkan kecepatan inovasi pasar yang baru dan perubahaan pola konsumsi para konsumen yang didukung oleh upaya pemebelajaran kolektif dari organisasi, khususnya bagaimana mengkoordinasi kecakapan memproduksi dan mengintegrasikan berbagai teknologi, organisasi kerja dan penyerahan nilai kompetensi inti (core competencies) perusahaan tersebut (M. Taufiq Amir, 2011: 89).

Balanced Scorecard adalah suatu metode untuk menerjemahkan strategi kedalam langkah-langkah komprehensif, koheran, seimbang, dan terukur untuk menerjemahkan kedalam empat perspektif, yaitu: keuangan, pelanggan, proses bisnis internal, serta proses pembelajaran dan pertumbuhan. Metode Balanced Scorecard memiliki beberapa keunggulan yaitu komprehensif, koheran, seimbang, dan terukur (Kaplan, 2007).

Balanced scorecard pada awalnya diciptakan untuk mengatasi problem tentang kelemahan sistem pengukuran kinerja yang berfokus pada aspek keuangan. Selanjutnya Balanced Scorecard mengalami perkembangan implementasinya tidak hanya sebagai alat pengukur kinerja, namun meluas sebagai pendekatan dalam penyusunan rencana strategik (Mulyadi, 2009).

Menururt (Kaplan dan McCann, 2008) Balanced scorecard memiliki 4 (empat) prespektik yaitu sebagai berikut:

1. Keuangan

Dalam perspktif finansial tolak ukur yang digunakan bergantung pada posisi perusahaan di daur hidup bisnis. Dari tahap-tahap perkembangan industri tersebut akan diperlukan strategistrategi yang berbeda-beda. Dalam perspektif Keuangan, terdapat tiga aspek dari strategi yang dilakukan suatu perusahaan; (1) pertumbuhan pendapatan dan kombinasi pendapatan yang dimiliki suatu organisasi bisnis, (2) penurunan biaya dan peningkatan 
produktivitas, (3) penggunaan aset yang optimal dan strategi investasi.

\section{Pelanggan}

Dalam perspektif pelanggan balanced scorecard, perusahaan melakukan identifikasi pelanggan dan segmen pasar yang akan dimasuki. Segmen pasar merupakan sumber yang akan menjadi komponen penghasilan tujuan finansial perusahaan. Perspektif pelanggan memungkin perusahaan menyelaraskan berbagai ukuran pelanggan, kepuasan, loyalitas, retensi, akuisisi dan profotabilitas dengan palanggan dan segmen pasar sasaran. Proposisi nilai merupakan faktor pendorong (lead indicator), untuk ukuran pelanggan penting.

3. Proses bisnis internal

Dalam perspektif proses bisnis internal, para eksekutif mengidentifikasi berbagai proses internal penting yang harus dikuasai dengan baik oleh perusahaan. Proses ini memungkinkan unit bisnis untuk memberikan proporsi nilai yang akan menarik perhatian dan mempertahankan pelanggan dalam segmen pasar sasaran dan memenuhi harapan keuntungan finansial yang tinggi para pemegang saham melalui ukuran proses bisnis internal berfokus kepada pada tiga proses bisnis utama yaitu: proses inovasi, proses operasi, proses paska penjualan.

4. Proses pembelajaran dan pertumbuhan

Perspektif keempat dari balanced scorecard, pembelajaran dan pertumbuhan, mengidentifikasi insfrastruktur yang harus dibangun perusahaan dalam menciptakan pertumbuhan dan peningkatan kinerja jangka panjang. Bagaimana mengembangkan organisasi itu menjadi organisasi belajar dan akhirnya menjadi organisasi yang tumbuh dan berkembang. Faktor belajar dan tumbuh sangat penting dalam sebuah organisasi, dengan faktor ini sebuah organisasi dapat terus berjalan dan hidup (Survive) atau tidak dimasa yang akan datang yang memasuki era persaingan yang cukup ketat. terdapat tiga dimensi penting yang harus diperhatikan untuk melakukan pengukuran yaitu; kemampuan karyawan, kemampuan sistem informasi, adanya motivasi, pemberian wewenang dan pembatasan wewenang kepada karyawan.

Penelitian terdahulu

Penelitian ini dilakukan tidak terlepas dari hasil penelitian-penelitian terdahulu yang pernah dilakukan sebelumnya untuk bahan perbandingan dan kajian. Adapun hasil-hasil penelitian yang dihasilkan perbandingan tidak terlepas dari topik penelitian yaitu mengenai evaluasi strategi dengan mengunakan metode balanced scorecard. Berdasarkan hasil penelitian yang pernah dilakukan oleh Sri wahyni (2011) dimana melakukan penelitian mengenai analisis balanced scorecard sebagai alat pengukuran kinerja pada PT. Semen Bosowa Maros. Hasil penelitianya menunjukan bahwa keempat presepektif pada balanced scorecard pada objek penelitian cukup baik.

Penelitian yang dilakukan oleh Ana Rohmatul Zulfa (2013) yang berjudul Analisis kinerja Transjakarta busway dalam kerangka balanced scorecard. Hasil penelitianya menunjukan bahwa kinerja keseluruhan Transjakarta busway di ukur dengan mengunakan metode balanced scorecard yang di tinjau dari perspektif pelanggan, perspektif keuangan, persepketif proses bisnis internal dan perspektif pertumbuhan dan pembelajaran dapat dikatakan baik.

\section{METODE}

Penelitian menggunakan metode kualitatif dengan jumlah populasi yang tidak besar maka sampel yang digunakan mengunakan teknik sampel incidental yang terdiri dari pemilik bisnis, 2 (dua) Karyawa dan 3 anggota (member) Spartan gym Pekanbaru.sedangkan batasan masalah dari lingkungan internal dan eksternal dengan tahapan analisis data penentuan visi dan misi, analisis lingkungan eksternal, analisis 
lingkungan internal, matrik IFAS dan EFAS, balanced scorecard.

\section{HASIL}

\section{Analisis Lingkungan internal}

Penelitian ini dilakukan pada Spartan gym kota pekanbaru yang sudah berdiri lebih dari 6 tahun lamanya didalam perjalanya beberapa kali pindah seperti di Panam, Harapan Raya dan di Jl. Wonosari kota Pekanbaru visi Spartan gym adalah "Menjadi pusat fitnes dan edukasi kesehatan dengan konsep dasar Manly, Energy dan Cozy di kota pekanbaru" dan misi pertama meningkatkan kualitas pelayanan dan fasiltas, kedua menjadi pusat edukasi, informasi, motivasi dan menawarkan produk-produk berkualitas.

Selama ini penjualan dan laba yang dihasilkan oleh Spartan gym Pekanbaru setiap tahunnya yaitu dari tahun 2012 sampai dengan 2014. Dari data tersebut terlihat perkembangan setiap tahunya, hal tersebut menunjukan bahwa kondisi keuangan Spartan gym berada diposisi panen (Harvest) dengan kondisi keuangan tersebut Spartan gym harus dapat mengendalikan dan mengatur pendapatan dengan tetap melakukan efesiensi dalam proses pelayanan.

Pada bidang pemasaran yang terdiri dari produk, harga, tempat dan promosi menunjukan bahwa Spartan gym terus melakukan inovasi dan pengembangan untuk memberikan pelayanan maksimal. Sedangkan pada sumber daya manusia (SDM) tenaga kerja yang dimiliki oleh Spartan gym sudah memadai dengan memiliki 10 orang karyawan yang memiliki keahlian masing-masing salah satunya pada instruktur training yang sudah bersertifikat.

\section{Analisis Lingkungan eksternal (Industri)}

Jika di sumpulkan secara keseluruhan berdasarkan daya tarik industri yang terdiri dari pemasok peralatan fitnes dan suplemen maka daya tawar-menawar pemasok di posisi sedang, pendatang baru di posisi sedang, pembeli di posisi rendah, pendatang baru di posisi sedang dan pesaing diposisi kuat. Berdasarkan ke lima fakor disimpulkan bahwa posisi Spartan gym dominan diposisi sedang hanya pada pesaing saja yang memiliki pengaruh yang kuat terhadap Spartan gym sedangkan sisanya pada Pembeli dan produk penganti berada diposisi rendah lihat tabel 1 .

Tabel 1. Posisi Eksternal Spartan Gym

\begin{tabular}{|l|l|l|l|l|}
\hline No & $\begin{array}{l}\text { Lima Faktor } \\
\text { Porter }\end{array}$ & Kuat & Sedang & Rendah \\
\hline 1 & Pendatang & & $\checkmark$ & \\
2 & Baru & $\checkmark$ & & \\
3 & Pesaing & & & $\checkmark$ \\
4 & Produk & & & $\checkmark$ \\
5 & Penganti & & $\checkmark$ & \\
& Pembeli & & & \\
& Pemasok & & & \\
\hline
\end{tabular}

Sumber : Data Olahan

\section{Matrik IFAS}

Untuk mengetahui bagaimana keadaan Spartan gym dapat dilihat dari sisi internal perusahaan yang dimasuk dalam sebuah tabel yaitu IFAS tabel tersebut akan diberikan skor, bobot, nilai dan nilai timbang seperti tabel 2 dibawah ini.

Tabel 2. Matrik IFAS

\begin{tabular}{|l|c|c|c|}
\hline Faktor Internal & Bobot & Nilai & $\begin{array}{c}\text { Nilai } \\
\text { Tertimbang }\end{array}$ \\
\hline Kekuatan & 0,0969 & 5 & 0,4845 \\
Citra Perusahaan & 0,0567 & 4 & 0,2268 \\
Keragaman Produk & 0,0464 & 3 & 0,1392 \\
Fasilitas dan kualitas & 0,0388 & 2 & 0,0776 \\
pelayanan & 0,1065 & 4 & 0,4224 \\
Mempunyai konsultan & & & \\
dari belanda & 0,0396 & 3 & 0,1188 \\
Memiliki banyak prestasi & 0,0198 & 2 & 0,0396 \\
dan penghargaan & 0,0598 & 3 & 0,1794 \\
Lokasi Strategis & & & \\
Harga Terjangkau & 0,4645 & & 1,6883 \\
Memiliki Instruktur & & & \\
Profesional & & & \\
Sub Total & & & \\
\hline Kelemahan & & & \\
Customer Service & 0,1069 & 4 & 0,4276 \\
kurang ramah & 0,0789 & 4 & 0,3156 \\
Promosi belum optimal & 0,0689 & 4 & 0,2756 \\
Raungan/Gedung masih & 0,1008 & 3 & 0,3024 \\
kecil & & & 1,3212 \\
Perlatan masih teknologi & 0,3555 & & \\
lama & & & \\
Sub Total & & & \\
\hline Total & 0,8209 & & \\
\hline
\end{tabular}

Berdasarkan tabel 2, menunjukan bahwa faktor citra perusahaan menunjukan skor tertinggi yaitu 0,4845 , hal tersebut dapat menjadi dasar pengembangan usaha Spartan gym. Faktor sarana dan prasarana seperti gedung merupakan kelemahan 
utama Spartan gym dengan nilai 0,2756. Sehingga dapat diketahui bahwa kelemahan paling utama di Spartan gym yaitu masih kurangnya melakukan perluasan gedung atau ruangan untuk menampung semua program atau produk yang di tawarkan oleh Spartan gym, namun jika untuk melayani fasiltas fitnes saja gedung yang tersedia sudah cukup luas. Total skor matrik IFAS sebesar 3,0095 yang berarti bahwa secara internal posisi perusahaan kuat. Sesuai dengan pendapat Umar (2003), jika total matrik IFAS 3,0-4,0 berarti perusahaan berada diposisi kuat.

\section{Matrik EFAS}

Berikut ini adalah hasil dari proses penghitungan untuk melihat lingkungan eksternal perusahaan tabel EFAS yang akan diberikan skor, bobot, nilai dan nilai timbang seperti Berdasarkan tabel 3, faktor meningkatnya pengatahuan masyarakat tentang pola hidup sehat menunjukan skor tertinggi yaitu 0,3912, Spartan gym kota Pekanbaru juga sudah memiliki lebih kurang 5000 anggota hal tersebut dapat menjadi peluang utama dalam pengembangan usaha Spartan gym, sedangkan skor terendah pada ancaman terdapat pada faktor banyaknya perusahaan sebagai pendatang baru dan pesaing dengan nilai skor yaitu 0,6875.Banyaknya pendatang baru untuk industri pusat kebugaran /fitnes dikota Pekanbaru serta jumlah pesaing yang semakin bertambah dan bermunculan merupakan ancaman utama bagi Spartan gym - berdasarkan hasil penghitungan dengan menggunakan tabel EFAS maka peneliti menemukan bahwa skor total pada matrik EFAS 2,0-3,0 berarti Spartan gym berada pada posisi rata-tara atau seimbang.

Tabel 3. Matrik EFAS

\begin{tabular}{|l|c|c|c|}
\hline Faktor Eksternal & Bobot & Nilai & $\begin{array}{c}\text { Nilai } \\
\text { Timbang }\end{array}$ \\
\hline $\begin{array}{l}\text { Peluang } \\
\text { Meningkatnya pengetahuan } \\
\text { masyarakat tentang pola hidup sehat } \\
\begin{array}{l}\text { Sudah memiliki pelanggan/member } \\
\text { sebanyak 5000 orang }\end{array}\end{array}$ & 0,0978 & 4 & 0,3912 \\
$\begin{array}{l}\text { Banyaknya perlombaan seperti } \\
\text { body contest di kota Pekanbaru }\end{array}$ & 0,0699 & 3 & 0,2097 \\
\hline
\end{tabular}

\begin{tabular}{|c|c|c|c|}
\hline $\begin{array}{l}\text { Kemampuan daya beli masyarakat } \\
\text { kota Pekanbaru tinggi } \\
\text { Media informasi yang semakin } \\
\text { mudah di akses untuk media } \\
\text { promosi } \\
\text { Peluang untuk membuka cabang } \\
\text { Sub Total }\end{array}$ & $\begin{array}{l}0,0542 \\
0,0601 \\
0,0476 \\
0,4159\end{array}$ & 3 & $\begin{array}{l}0,1428 \\
1,3717\end{array}$ \\
\hline $\begin{array}{l}\text { Ancaman } \\
\text { Banyaknya perusahaan sebagai } \\
\text { pendatang baru }\end{array}$ & 0,1508 & 4 & 0,6032 \\
\hline Banyak jumlah pesaing & 0,1375 & 5 & 0,6875 \\
\hline Pengaruh Inflasi kota Pekanbaru & 0,0926 & 3 & 0,2778 \\
\hline Sub Total & 0,3809 & & 1,5685 \\
\hline Total & 0,7968 & & 2,9402 \\
\hline
\end{tabular}

Sumber : Data Olahan

\section{Balanced scorecard}

Pada tahapan ini peneliti akan mengevaluasi strategi Spartan gym kota Pekanbaru dengan melihat dari analisis internal dan eksternal selanjutnya dilakukan perhitungan dari perspektif keungan, perspektif pelanggan, perspektif proses bisnis internal dan perspektif pembelajaran dan pertumbuhan.

\section{Perspektif keuangan}

Tabel 4. Kinerja prespektif keuangan tahun 2014

\begin{tabular}{|l|l|l|l|l|}
\hline $\begin{array}{l}\text { N } \\
\text { o }\end{array}$ & $\begin{array}{l}\text { Tolak } \\
\text { Ukur }\end{array}$ & Target 2014 & $\begin{array}{l}\text { Realisasi } \\
2014\end{array}$ & $\begin{array}{l}\% \\
\text { Realis } \\
\text { ai th } \\
\text { Target }\end{array}$ \\
\hline 1 & $\begin{array}{l}\text { Tingkat } \\
\text { Pendapata } \\
\text { n }\end{array}$ & $\begin{array}{l}\text { Rp } \\
502.400 .50 \\
0,-\end{array}$ & $\begin{array}{l}\text { Rp } \\
300.050 .40 \\
0,-\end{array}$ & $59,8 \%$ \\
\hline 2 & Tingkat & Rp & Rp & $74,9 \%$ \\
& $\begin{array}{l}\text { Pembelanj } \\
\text { an }\end{array}$ & 601.070 .50 & 450.050 .10 & $0,-$ \\
0 & $0,-$ & \\
\hline \multicolumn{4}{|c|}{ Berdasarakn tabel 4 diatas, }
\end{tabular}

peneriman pendapatan kurang dari target yang ditentukan yaitu sebesar 59,8\%. Kemudian realisasi tingkat belanja pada tahun 2014 kurang $25.1 \%$ dari yang telah ditetapkan.

\section{Perspektif Pelanggan}

Tabel 5. Retensi Pelanggan

\begin{tabular}{|l|l|l|l|}
\hline No & Tahun & $\begin{array}{l}\text { Target } \\
\text { anggota }\end{array}$ & $\begin{array}{l}\text { Jumlah } \\
\text { anggota }\end{array}$ \\
\hline 1 & 2013 & - & 334 orang \\
\hline 2 & 2014 & 500 orang & 487 orang \\
\hline
\end{tabular}

Sumber: data olahan 2015 
Dari data diatas maka dapat dihitung besarnya retensi pelanggan dalam hal ini retensi pelanggan di Spartan Gym yaitu dengan rumus:

$$
\begin{aligned}
\text { Retensi Pelanggan } & =\frac{\sum \text { Member tahun } 2014}{\sum \text { Member tahun } 2013} \times 100 \% \\
\text { Retensi Pelanggan } & =\frac{487 \text { orang }}{334 \text { orang }} \times 100 \% \\
& =145.8 \%
\end{aligned}
$$

\section{Perspektif proses bisnis internal}

Pada perspektif ini Spartan memiliki kesedian peralatan yang terus dikembangkan dengan jumlah 90 unit. Untuk instruktur yang dimiliki berjumlah 3 orang dengan tingkat kesedian instruktur sebesar $81 \%$.

\section{Prespektif pembelajaran dan pertumbuhan}

Pada perspektif ini Spartan gym memiliki tingkat retensi pekerja dan pelatihan pekerja seperti tabel 5. Kinerja perspektif petumbuhan dan pembelajaran dari tingkat retensi pegawai $0,1 \%$ dan tingkat pelatihan pekerja sebesar $80 \%$.

Tabel 6. Pertumbuhan dan pembelajaran

\begin{tabular}{|l|l|l|l|}
\hline No & Tolak Ukur & Target & Realisasi \\
\hline 1 & Retensi Pekerja & $\begin{array}{l}0 \% \\
0 \\
\text { orang }\end{array}$ & $\begin{array}{l}0,1 \% \\
1 \text { orang }\end{array}$ \\
\hline 2 & $\begin{array}{l}\text { Tk. Pelatihan } \\
\text { Pekerja }\end{array}$ & $100 \%$ & $80 \%$ \\
\hline
\end{tabular}

Sumber: data olahan

Berdasarkan data yang telah di hitung dari ke empat perspektif dari balanced scorecard diketahui nilai keseluruhan dari kinerja Spartan gym kota pekanbaru dengan nilai baik lihat tabel 7. Kenerja keselurahan

\begin{tabular}{|c|c|c|c|c|c|c|c|}
\hline $\begin{array}{l}\mathrm{N} \\
\mathrm{o}\end{array}$ & $\begin{array}{l}\text { Tolak } \\
\text { Ukur } \\
\text { Perspektif }\end{array}$ & $\begin{array}{l}\text { Targ } \\
\text { et }\end{array}$ & $\begin{array}{l}\text { Realisa } \\
\text { si }\end{array}$ & $\begin{array}{l}\text { Nila } \\
\mathrm{i} \\
\text { Tola } \\
\mathrm{k} \\
\text { Uku } \\
\mathrm{r}\end{array}$ & $\begin{array}{l}\text { Nilai } \\
\text { perspek } \\
\text { tif }\end{array}$ & $\begin{array}{l}\text { Bob } \\
\text { ot }\end{array}$ & $\begin{array}{l}\text { Nilai } \\
\text { Kinerj } \\
\text { a }\end{array}$ \\
\hline $\begin{array}{c}(1 \\
)\end{array}$ & (2) & (3) & (4) & (5) & $\begin{array}{c}(6)=\mathrm{Me} \\
\text { an (5) }\end{array}$ & 7 & $\begin{array}{c}8=(7 x \\
6)\end{array}$ \\
\hline \multicolumn{8}{|c|}{ Perspektif Kuangan } \\
\hline 1 & $\begin{array}{l}\text { Tingkat } \\
\text { Pendapata }\end{array}$ & 100 & $59,8 \%$ & 3 & & & \\
\hline
\end{tabular}
Spartan gym

\begin{tabular}{|c|c|c|c|c|c|c|c|}
\hline & $\mathrm{n}$ & $\%$ & & & \multirow[t]{2}{*}{3,5} & \multirow[t]{2}{*}{0.25} & \multirow[t]{2}{*}{0.875} \\
\hline 2 & $\begin{array}{l}\text { Tingkat } \\
\text { Pembelan } \\
\text { jan }\end{array}$ & $\begin{array}{l}100 \\
\%\end{array}$ & $74,9 \%$ & 4 & & & \\
\hline \multicolumn{8}{|c|}{ Perspektif Pelangga } \\
\hline 1 & $\begin{array}{l}\text { Retensi } \\
\text { Pelangga }\end{array}$ & $\begin{array}{l}100 \\
\%\end{array}$ & $(97 \%)$ & 5 & \multirow[t]{2}{*}{3,9} & \multirow[t]{2}{*}{0.28} & \multirow[t]{2}{*}{1.092} \\
\hline 2 & $\begin{array}{l}\text { Tingkat } \\
\text { Pengadua } \\
\mathrm{n}\end{array}$ & $0 \%$ & $\begin{array}{l}(0.196 \\
\%)\end{array}$ & 4 & & & \\
\hline \multicolumn{8}{|c|}{ Perspektif Proses Bisnis Internal } \\
\hline 1 & $\begin{array}{l}\text { Ketersedi } \\
\text { an } \\
\text { peralatan }\end{array}$ & $\begin{array}{l}100 \\
\%\end{array}$ & $(100 \%)$ & 5 & \multirow[t]{2}{*}{3,9} & \multirow[t]{2}{*}{0,29} & \multirow[t]{2}{*}{1.131} \\
\hline 2 & $\begin{array}{l}\text { Ketersedi } \\
\text { an } \\
\text { instrukutu } \\
r\end{array}$ & $\begin{array}{l}110 \\
\text { oran } \\
g\end{array}$ & $(81 \%)$ & 4 & & & \\
\hline \multicolumn{8}{|c|}{ Perspektif Pertumbuhan dan Pembelajaran } \\
\hline 1 & $\begin{array}{l}\text { Retensi } \\
\text { Pekerja }\end{array}$ & $\begin{array}{l}0 \% \\
(0 \\
\text { oran } \\
\mathrm{g})\end{array}$ & $\begin{array}{l}0,1 \% \\
(10 \\
\text { orang) }\end{array}$ & 3 & \multirow[t]{3}{*}{3,5} & \multirow[t]{2}{*}{0,25} & \multirow[t]{2}{*}{0.875} \\
\hline 2 & $\begin{array}{l}\text { Pelatihan } \\
\text { Kerja }\end{array}$ & $\begin{array}{l}100 \\
\%\end{array}$ & $80 \%$ & 4 & & & \\
\hline \multicolumn{5}{|c|}{ JUMLAH } & & \multicolumn{2}{|c|}{$\begin{array}{l}0.913 \\
\text { BAIK } \\
\end{array}$} \\
\hline
\end{tabular}

Tabel 7. Kinerja keselurahan Sparrtan gym
Sumber : Data olahan 2015

Dengan melihat tabel 7. Tentang kinerja keseluruhan Spartan gym kota Pekanbaru maka dibuatlah kerangka balanced scorecard seperti pada gambar 1 dibawah ini.

Gambar 1. Kerangka kerja Balanced Scorecard Spartan Gym

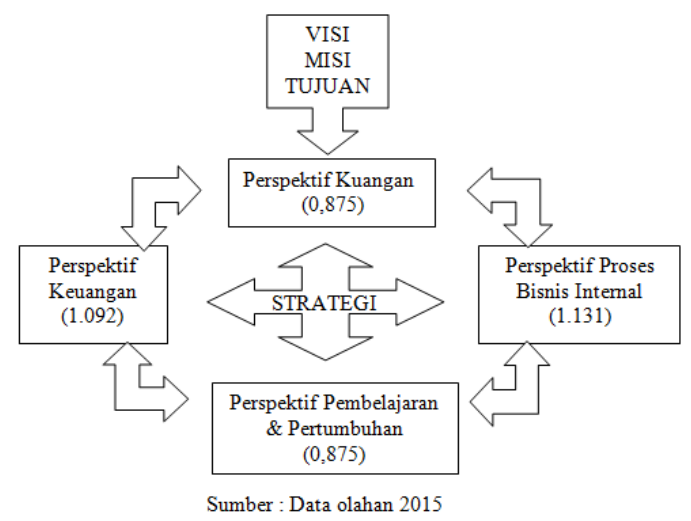

\section{PEMBAHASAN}

\section{Lingkungan Internal}

Berdasarkan tabel matrik IFAS yang gunakan untuk menganalisis lingkungan internal peneliti menemukan bahwa keadaan Spartan gym kota Pekanbaru dalam keadaan baik dengan total 
skor matrik IFAS sebesar 3,0095 yang berarti bahwa secara internal posisi perusahaan kuat. Sesuai dengan pendapat Umar (2003), jika total matrik IFAS 3,0-4,0 berarti perusahaan berada diposisi kuat. Menurut pendapat Freddy Rangkuti (2008) jika hasil nilai IFAS berada di posisi baik dengan skala 3,0-4,0 maka perusahaan di nyatakan baik dengan keadaan tersebut Spartan gym dapat mengembangkan strategi dan tetap menjaga keadaan tetap stabil karena ada ada kekewatiran bisa saja di poisisi bertahan (stabilisasi) Suwarsono (Muhammad, 2008).

Dengan keadaan posisi yang baik maka Spartan dapat melakukan beberapa strategi salah satunya strategi stabilisasi. Strategi Stabilisasi merupakan strategi yang dilakukan oleh perusahaan tanpa membuat strategi baru karena perusahaan tersebut focus dengan keadaaan sekarang atau strategi sekarang beberapa strategi stabilisasi seperti no change, pause dan profit (whellen \& Hunger, 2008).maka Spartan gym kota pekanbaru dapat melakukan strategi salah satunya meningkatkan dan memaksimalkan pelayanan yang diberikan sekarang seperti peningkatan motivasi para pegawai Spartan gym agar dapat bekerja lebih optimal. Motivasi dapat dilakukan melalui pelatihan atau mengali faktor kebutuhan (Maslow, 1998).

\section{Lingkungan Eskternal}

Pada lingkungan eskternal Spartan gym berdasarkan hasil penghitungan dengan menggunakan tabel EFAS maka peneliti menemukan bahwa skor total pada matrik EFAS 2,0-3,0 berarti Spartan gym berada pada posisi rata-tara atau seimbang. Menurut Umar (2003) jika hasil dari matrik EFAS menunjukan nilai dengan rata-rata 2,0-3,0 maka keadaan antara ancaman dan peluang dalam keadaan baik atau seimbang dan bisa memanfaatkan peluang yang dimiliki dengan kekuaran yang dimiliki oleh Spartan Gym Mahmud (2008). Pada penelitian yang dilakukan oleh reni $\mathrm{w}$, arif hidayat, Ika asari (2013) menyebutkan bahwa jika keadaan poisisi matrik EFAS berada di posisi seimbang maka perusahaan dapat menfaatkan peluang dengan menfaatkan kekuatan yang dimiliki jadi Sprtan gym dapat meningkatkan kegiatan promosi tentang pola hidup sehat kepada masyarakat pekanbaru dengan cara aktif membuat kampaye tentang pola hidup sehat di media elektronik maupun di media social atau membuat browser dan membagikan ke pada masyarakta pada even even olahraga seperti car free day (CFD) yang sering diadakan pada hari minggu dijlana penogoro kota pekanbaru. Dengan strategi yang dilakukan para pesaing akan semakin tertekan dan tersaingi karena strategi yang sudah diterapkan.

\section{Balanced scorecrad}

Penilian Balanced scorecrad merupakan tahapan terkahir pada penelitian ini setelah melakukan analisis internal dan eksternal yang akan menjadi sumber pertimbangan dalam evaluasi strategi Spartan gym kota pekanbaru Hasil dari penghitungan keempat persepktif yang terdiri dari perspektif keuangan menunjukan nilai 0,875 yang berarti sehat sesuai dengan hasil penelitian yang dilakukan oleh (Ana Rohmotual Zulfa, 2013) melakukan penelitian pada Bus Way Jakarta. Sedangkan menurut Kaplan \& Norton (2000) jika nilai persepktif keuangan perusahaan di 3,5 maka disarankan untuk strategi bertahan (sustain stage) strategi ini menyarankan untuk tetap melakukan investasi diengan harapan pengembalian terbaik.

Berikutnya persepektif pelanggan menunjukan nilai perspektif 3,9 menunjukan nilai baik. Nilai ini menunjukan tingkat resistensi dan pengaduan cukup renndah terhadap Spartan gym.. pada perspektif bisnis internal proses yang terdiri dari kesedian perlatan dan instruktur menunjukan nilai persepktif di 3,9 dimana Spartan gym melakukan meningkatkan ketersedian pelaralatan fitness yang modern, kebersihan, ruangan, instruktur yang sudah memiliki perstasi dan sertifikat serta sering ikut perlobaan bodycontest untuk meningkatkan kasfisaitas 
pengetahuan instruktur serta membuat jadwal terstruktur setiap hari.

Strategi ini harus dipertahankan dan ditingkatkan dan perspektif terakhir adalah pengembangan dan pembelajaran menunjukan nilai 3,5 ini berarti tingkat percapian dari target yang sudah direncanakan diawal sesuai dengan harapan dimana Spartan gym berhasil menjaga hubungan baik dengan para karyawn yang dimilki dan untuk pelatihan mencapai nilai $80 \%$ dari target yang dibuat.tidakan yang bisa dilakukan pada pesrpektif ini adalah tetap melakukan evaluasi terhadapa kinerja karyawan, meningkatkan koordinasi tentang pelatihan khususnya bagi instruktur fitness, yoga, martial art dan erobik.

Berdasarkan hasil penelian yang dilakukan dari keempat persepktif tersebut maka peneliti mengambil kesimpulan evaluasi kinerja strategi yang dilakukan pada Spartan gym dengan mengunakan metode balanced scorecard adalah baik. Temuan ini menunjukan bahwa peneliti setuju bahwa metode balanced scorerad dapat di guanakan sebagai alat atau model evaluasi strategi mendukung penyataan dari Kaplan dan Norton (2000) yang menyatakan bahwa manfaat dari balanced scorecard dapat membantu perusahan untuk melihat dan mengevaluasi kinerja perusahaan. Sedangkan menurut Monika kussetnya ciptani (2000) dalam jurnalnya yang berjudul balanced scorecard sebagai pengukuran kinerja dimasa depan: sebuah pengantar menyumpulkan bahwa konsep ini akan membantu perusahaan untuk melakukan pengukuran kinerja secara komprehensif dan akurat.

Penelitian ini juga mendukung penelitian sebelumnya yang dilakukan Ana Rohmatul Zulfa (2013) yang berjudul Analisis kinerja Transjakarta busway dalam kerangka balanced scorecard. Hasil penelitianya menunjukan bahwa kinerja keseluruhan Transjakarta busway di ukur dengan mengunakan metode balanced scorecard yang di tinjau dari perspektif pelanggan, perspektif keuangan, persepketif proses bisnis internal dan perspektif pertumbuhan dan pembelajaran dapat dikatakan baik.

\section{SIMPULAN}

Setalah dilakukan pembuatan hasil dan pembahasan pada penelitian ini disumpulkan beberapa hal yaitu Spartan gym berada dalam keadaan baik berdasarkan dari empat persepektif yang dinilai yaitu perspektik keuangan, perspektif pelanggan, perspektif binis proses internal dan persepktif pengembangan dan pembelajaran serta melihat lingkungan internal dan eksternal, pada lingkungan internal Spartan gym menunjukan nilai yang baik sedangkan dilingkungan eksternal juga menunjukan nilai diposisi seimbang. Penelitian ini juga menyetuji/ mendukung penelitian sebelumnya bahwa metode balanced scorecard dapat membantu perusahaan dalam pengkururan kinerja perusahaan secara komprehensif dan akurat.

\section{DAFTAR RUJUKAN}

Dewi. Andri. 2012. Perencanaan Strategi Pengembangan Usaha Kain Tenun Sutra Dengan Pendekatan Metode Balanced Scorecard (Studi Kasus Di Pabrik Sutra Tiga Putra). Jurnal Sttgarut. Vol. 10 No.1 h. 1-12

Fred R. David, 2010. Manajemen Strategik Konsep, Salemba Empat, Jakarta

Hansen dan Mowen, 2009. Akuntansi Manajemen, Edisi ke 8, Penerbit salemba empat, Jakarta

Husein Umar. 2002. Strategic Management in Action. Gramedia Pustaka Utama, Jakarta

Ismail Solihin, 2012. Manajemen Strategik., Erlangga, Jakarta

M. Taufiq Amir, 2011. Manajemen Strategik Konsep dan Aplikasi., PT. Rajagrafindo Persada, Jakarta 
Mulyadi. 2001. Balanced Scorecard. Alat Manajemen Kontemporer Untuk Pelipat ganda Kinerja Keuangan Perusahaan. (Edisi Ke-2), Salemba Empat, Jakarta

Mulyadi.2009.Sistem Terpadu Pengelolaam Kinerja Personel Berbasis Balanced Scorecard.. Erlangga, Yogyakarta.

Moses, Kristiana, Renny. 2001. Pengukuran Dan Analisa Kinerja Dengan Metode Balanced Scorecard Di Pt. "X”, Jurnal Teknik Industri. Vol.3 No.2. h 48-51

Nyoman, Komang. 2013. Penilaian Kinerja Berbasis Balanced Scorecard Pada Bank Utama, E-Jurnal Akuntansi, Vol. 5.2 No 1. h.497-515

Kaplan, R.S. \& Norton, D.P. 1996. Linking The Balanced Scorecard Into Strategy. Harvard Business School Press, Boston

Kaplan, S. Robert, dan David, P. Norton, 2000. The Balanced Scorecard: Translating Strategy into Action, Edisi satu,: Harvard Business School Press, Boston, United States of America

Kuncoro, M. 2006. Strategi Bagaimana Meraih Keunggulan Kompetitif, Erlangga, Jakarta

Sugiyono, 2007. Statistika untuk penelitian, Alphabets, Bandung

Swarsono Muhammad, 2008. Matriks \& Skenario dalam Strategi, UPP STIM YKPN, yogyakarta

Thompson, A. A., Strickland III, A. J. and Gamble, J. E. 2010. Crafting and Executing Strategy: The Quest For Competitive Advantage: Concepts and Case. Seventeenth Edition. McGrawHill.
Wheelen, dan Hunger, 2004. Strategic Management and Business Policy, Ed. 9, Prentice Hall.

2004. Concepts in Strategic Management and Bisnis Policy, ED. 9, Pearson Prentice Hall. 